\title{
Arthropods inhabiting flowering non-crop plants and adaptive vegetables planted around paddy fields of freshwater swamps of South Sumatra, Indonesia
}

\author{
SITI HERLINDA ${ }^{1,2,3,}$, TILI KARENINA ${ }^{2,4}$, CHANDRA IRSAN ${ }^{1,2,3}$, YULIA PUJIASTUTI ${ }^{1,2,3}$ \\ ${ }^{1}$ Department of Plant Pests and Diseases, Faculty of Agriculture, Universitas Sriwijaya. Jl. Raya Palembang-Prabumulih Km 32, Indralaya, Ogan Ilir \\ 30662, South Sumatra, Indonesia. Tel.: +62-711-580663, Fax.: +62-711-580276, `email: sitiherlinda@unsri.ac.id \\ ${ }^{2}$ Agriculture Sciences Graduate Program, Faculty of Agriculture, Universitas Sriwijaya. Jl. Padang Selasa No. 524, Bukit Besar, Palembang 30139, South \\ Sumatra, Indonesia \\ ${ }^{3}$ Research Center for Sub-optimal Lands (PUR-PLSO), Universitas Sriwijaya. Jl. Padang Selasa No. 524, Bukit Besar, Palembang 30139, South Sumatra, \\ Indonesia \\ ${ }^{4}$ Research and Development Agency of South Sumatera Province. Palembang 30136, South Sumatra, Indonesia
}

Manuscript received: 29 September 2019 Revision accepted: 27 October 2019

\begin{abstract}
Herlinda S, Karenina T, Irsan C, Pujiastuti Y. 2019. Arthropods inhabiting flowering non-crop plants and adaptive vegetables planted around paddy fields of freshwater swamps of South Sumatra, Indonesia. Biodiversitas 20: 3328-3339. Local farmers in freshwater swamps of South Sumatra traditionally plant adaptive flowering vegetables surrounding paddy fields and let wild flowering plants or non-crop plants grow on the embankment. This research aimed to determine the species of non-crop plants and adaptive vegetables surrounding the freshwater swamp paddy fields as habitats and niches of arthropods. This study used four species of flowering non-crop plants (Zinnia sp., Tagetes erecta, Cosmos caudatus, Sesamum indicum) and four species of vegetables (Vigna unguiculata, Momordica charantia, Cucumis sativus, Luffa acutangula) planted around the paddy fields. While the arthropods were collected using sweep nets. There were 24 species of predatory arthropods, three species of parasitoids, 17 species of herbivores, and nine species of neutral insects found in the non-crop plants and vegetables. The non-crop plant and vegetable species that were the most chosen by the predatory arthropods were Zinnia sp. and M. charantia, respectively. Species of the non-crop plants and vegetables chosen by the parasitoids were $T$. erecta and $M$. charantia, respectively. Those non-crop plants and adaptive vegetables were also the most chosen plants by the predatory arthropods for their habitats and niches. Therefore, for the conservation of natural enemies, it is better to use Zinnia sp., T. erecta, and M. charantia.
\end{abstract}

Keywords: Herbivores, neutral insects, parasitoids, predatory arthropods, predatory insects

\section{INTRODUCTION}

Freshwater swamps are wetlands saturated with water, either throughout the year or seasonally due to the influence of river water or rain. In Indonesia. Freshwater swamps reach 9.2 Mha spreading across Sumatra, Kalimantan, and Papua (Mulyani and Sarwani, 2013). Freshwater swamps have three land typologies, namely shallow, middle, and deep, generally cultivated as adaptive plants (Siaga et al. 2019). All of the three land typologies are generally planted with paddy (Herlinda et al. 2018; Lakitan et al. 2018; Prabawati et al. 2019). On paddy fields planted in the shallow and middle swampy of lowlands, they are generally also planted with adaptive vegetables, such as chili (Johari et al. 2014, 2016), long beans, bitter melon, ridged gourd, eggplant, and cucumber (Siaga et al. 2019). On the embankments not planted with adaptive vegetables, they are generally not weeded, but wild plants (non-crop plants) can still grow there (Herlinda et al. 2019; Karenina et al. 2019). In addition, local farmers are not accustomed to applying synthetic pesticides (Herlinda et al. 2018).

Unnoticed by the farmers, the wild vegetables and plants can act as habitats and arthropod niches both as natural enemies and insect pests (Hassan et al. 2016;
McCabe et al. 2017). Apart from being alternative habitats and niches for natural enemies, these wild vegetables and plants also act as niches due to providers of nectar and pollen (Karenina et al. 2019). The nectar and pollen can increase the longevity, fecundity, and fitness of adult natural enemies (Desai et al. 2017; Foti et al. 2017).

Some previous researches on the arthropods inhabiting plants have been done. According to Desai et al. (2017), in some species of flowering non-crop plants, for example, Zinnia sp., spiders (Argiope aemula, Oxyopes sp., and Perenethis sp.) are found settling. Furthermore, Tagetes erecta is inhabited by Oxyopes javanus, Coccinella septumpunctata, Syrphus spp., Geoceris spp., Apis dorsata, A. mellifera, and Vanessa cardui (Ganai et al. 2017). The natural enemies of predatory arthropods, namely Pentatomidae and Mantidae and parasitoids from Eulophidae, Tachinidae, and Icheneumonidae are found in non-crop plants (Antigonon leptopus, Turnera subulata, and Agreratum sp.) (Saleh and Siregar 2017).

Paddy of freshwater swamps surrounded by vegetables, such as $V$. sinensis, C. sativus, $M$. charantia, and $L$. acutangula has an abundance and variety of arthropod predator species more than that not surrounded by the four vegetable species mentioned above (Karenina et al. 2019). 
Consequently, it is necessary to find out the species of noncrop plants and adaptive vegetables as habitats and niches of arthropods, especially predatory arthropods and parasitoids as natural enemies of paddy pest insects. The study aimed to determine the species of non-crop plants and adaptive vegetables surrounding the freshwater swamp paddy fields as habitats and niches of arthropods.

\section{MATERIALS AND METHODS}

The study was carried out in the freshwater swamp paddy fields of Pelabuhan Dalam Village in Pemulutan Subdistrict of Ogan Ilir District of South Sumatra Province from May to November 2018. The identification of arthropod species was conducted from December to March 2019 by Dr. Chandra Irsan from Universitas Sriwijaya. The location of the study was carried out in a freshwater swamp paddy center surrounded by monoculture paddy on an area of \pm 800 ha. In this study, four species of non-crop plants were planted in paddy fields surrounding 1 ha of freshwater swamp paddy and 1 ha of the other paddy plots was surrounded by four species of local vegetables planted in the embankment of paddy fields.

\section{Growing Non-crop plants and vegetables}

The planting of non-crop plants and vegetables was carried out 30 days before planting paddy so that when it reached 14 days after transplanting (DAT), the non-crop plants and vegetables began to bloom. There were two paddy plots of 1 ha each. The first plot was surrounded by four species of non-crop plants: zinnia (Zinnia sp.), marigold (Tagetes erecta), kenikir (Cosmos caudatus), and sesame (Sesamum indicum) planted on four sides of the embankment. The second plot was surrounded by four species of vegetables: cowpea (Vigna unguiculata), bitter melon (Momordica charantia), cucumber (Cucumis sativus), and ridged gourd (Luffa acutangula). The spacing between planting holes was $30 \mathrm{~cm}$ for long beans, $60 \mathrm{~cm}$ for bitter melons, $40 \mathrm{~cm}$ for cucumbers, and $30 \mathrm{~cm}$ for ridged gourd. As for non-crop plants, the spacing between planting holes was $15 \mathrm{~cm}$.

\section{Paddy planting}

The stages of paddy planting started from tillage, seed treatment, nursery, transplanting, and fertilizing using manure and liquid compost extract. Land preparation and processing began with clearing weeds and then soil treatment while applying manure at a dose of 1 ton.ha ${ }^{-1}$ and liquid compost extract at a dose of 2 L.ha $^{-1}$. Liquid compost extract was made following the method of Suwandi et al. (2012) enriched with Trichoderma virens. The paddy seeds used mekongga variety, which was already treated using compost extract when ripening the seeds for 1 x 24 hours. After that, the seeds were sown and covered with a banana leaf on a plastic tray (size $36 \mathrm{~cm} \mathrm{x} 27 \mathrm{~cm} \mathrm{x} 4.5 \mathrm{~cm}$ ) for 14 days. The 14-day-old paddy seedlings were transplanted into the fields with the 2:1 legowo row system with a planting space of $50 \mathrm{~cm} \times 25 \mathrm{~cm}$ x $12.5 \mathrm{~cm}$.

\section{Observation of arthropod inhabiting non-crop plants and vegetables}

The observation of arthropod inhabiting non-crop plants and vegetables surrounding the paddy was conducted once a week, starting when the paddy reached 14 to 84 days after transplanting. This observation was a continuation of the research of Karenina et al. (2019) who sampled by taking five flowers for each species of non-crop plants and vegetables, while in this study the sampling was carried out by observing directly and documenting arthropods that perched on non-crop plants flowers or leaves and vegetables at 07-08 a.m., 09-10 a.m., 12-01 p.m., and 0405 p.m. Direct observations were conducted on five flowers for each species of non-crop plants and vegetables. The observations were made by recording and documenting the arthropods that perched. The inhabiting arthropods were identified based on their morphological characteristics. Identification of spiders referred to Barrion and Litsinger (1995) and identifying insects referred to Heinrichs (1994), Kalshoven (1981), and McAlpine et al. (1987).

\section{Data analysis}

Arthropod composition and abundance data on noncrop plants and vegetables were analyzed descriptively and presented in tables and graphs. The arthropod abundance data were also further grouped by guild, namely predator (spiders and predatory insects), parasitoids, herbivores, and neutral insects to be displayed in graphical form. Data presented in Tabel 1-4 were counted from the mean of arthropod abundance from five flowers for each species of the plants during 11 observations (11 weeks). Data of Figure 2 were obtained from proportion of the total abundance of each guild and the total abundance of all guilds. The mean of arthropod family abundance from each plant was presented in Figure 3. Data of Figure 4 were obtained from the mean of abundance from each guild (predatory arthropod, parasitoids, herbivores, and neutral insects). Data presented in Figure 5 were counted from the mean of abundance from each guild sampled at 07-08 a.m, 09-10 a.m, 12-01 p.m, 04-05 p.m. Data for Figure 6 were obtained from the mean of arthropod abundance from each observation since 14 until 84 days.

\section{RESULTS AND DISCUSSION}

\section{Arthropod abundance inhabiting non-crop plants and vegetables}

Dominant arthropods inhabiting non-crop plants and vegetables were Cosmophasis sp., Tetragnatha mandibulata, Oxyopes javanus, Oxyopes sp., Odontoponera transversa, Menochilus sexmaculatus, Pantala sp., and Odontomantis planiceps (Figure 1). The most dominant species of predatory arthropods at non-crop plants were Odontomantis planiceps, while at the vegetables, it was Coccinellidae (unknown species). During one paddy planting season, 24 species of predatory arthropods (spiders and predatory insects) were found inhabiting non-crop plants and vegetables. The species of non-crop plants most chosen by the predatory arthropods 
was zinnia (0.271 individuals/hill), while the adaptive vegetable chosen was bitter melon (0.039 individuals/hill) (Table 1). The number of species of predatory arthropods in zinnia and bitter melons was the largest, comprising 15 species and 6 species, respectively.

The parasitoid species found in non-crop plants were a large number of Blondelia nigripes, while those found in vegetables were Sarcophagidae (Table 2). During the paddy planting season, there were found 3 species of parasitoid families inhabiting the non-crop plants and vegetables. The highest parasitoid abundance in non-crop plants was found in zinnia and the highest parasitoid abundance in vegetables was found in bitter melons.

Species of herbivores or phytophagous species found in non-crop plants were Pelopidas thrax, while the species most commonly found in vegetables was Aulacophora frontalis (Table 3). During the paddy planting season, 17 species of herbivores were found inhabiting non-crop plants and vegetables. The highest abundance of herbivores in non-crop plants was found in zinnia and the highest abundance of herbivores in vegetables was found in the ridged gourd.

The species of neutral insects found in non-crop plants and vegetables was Odontoponera transversa. During the paddy planting season, nine species of neutral insects were found inhabiting non-crop plants and vegetables (Table 4). The highest abundance of neutral insects in non-crop plants was found in sesame, and the highest abundance of neutral insects in vegetables was found in cowpeas.

Table 1. Predatory arthropod abundance inhabiting non-crop plants and vegetables

\begin{tabular}{|c|c|c|c|c|c|c|c|c|}
\hline \multirow{2}{*}{ Species } & \multicolumn{8}{|c|}{ Predatory arthropod abundance inhabiting non-crop plants and vegetables (individual/hill) } \\
\hline & Zinnia & Marigold & Kenikir & Sesame & Cowpea & Bitter melon & Cucumber & Ridged gourd \\
\hline Pardosa sp. & 0.009 & 0 & 0 & 0 & 0 & 0 & 0 & 0 \\
\hline Argiope sp. & 0.005 & 0 & 0 & 0 & 0 & 0 & 0 & 0 \\
\hline Tetragnatha virescens & 0 & 0 & 0 & 0 & 0.005 & 0 & 0 & 0 \\
\hline Tetragnatha mandibulata & 0.023 & 0 & 0.005 & 0 & 0 & 0 & 0 & 0 \\
\hline Linyphiidae (unknown sp.) & 0 & 0 & 0.005 & 0 & 0 & 0 & 0 & 0 \\
\hline Oxyopes matiensis & 0.032 & 0 & 0 & 0.005 & 0 & 0 & 0 & 0 \\
\hline Oxyopes javanus & 0.005 & 0 & 0 & 0 & 0 & 0 & 0 & 0 \\
\hline Thomisidae (unknown ) & 0 & 0.005 & 0 & 0 & 0 & 0 & 0 & 0 \\
\hline Cosmophasis sp. & 0.045 & 0.018 & 0 & 0.014 & 0 & 0 & 0 & 0 \\
\hline Salticidae (unknown sp.) & 0.005 & 0 & 0 & 0 & 0 & 0 & 0 & 0 \\
\hline Menochilus sexmaculatus & 0.014 & 0.005 & 0 & 0.005 & 0 & 0.014 & 0.009 & 0.009 \\
\hline Coccinellidae (unknown sp.) & 0.005 & 0.009 & 0 & 0 & 0 & 0.005 & 0.018 & 0 \\
\hline Formicomus sp. & 0.000 & 0.009 & 0.005 & 0 & 0 & 0 & $\begin{array}{c}0.010 \\
0\end{array}$ & 0 \\
\hline Paederus fuscipes & 0.005 & 0 & 0 & 0 & 0 & 0.005 & 0 & 0 \\
\hline Chloropidae (unknown sp.) & 0 & 0.032 & 0.005 & 0 & 0 & 0 & 0 & 0 \\
\hline Chrysosoma leucopogon & 0.018 & 0.005 & 0 & 0 & 0 & 0.005 & 0 & 0 \\
\hline Eristalinus sp. & 0.005 & 0 & 0 & 0 & 0 & 0.005 & 0 & 0 \\
\hline Eristalis sp. & 0 & 0.009 & 0.018 & 0 & 0 & 0.005 & 0 & 0 \\
\hline Ropalidia marginata & 0 & 0 & 0.005 & 0 & 0 & 0 & 0 & 0.005 \\
\hline Odontomantis planiceps & 0.068 & 0 & 0 & 0.005 & 0 & 0 & 0 & 0 \\
\hline Archimantis sp. & 0 & 0 & 0.014 & 0 & 0 & 0 & 0 & 0 \\
\hline Mantidae (unknown sp.) & 0.014 & 0 & 0 & 0.005 & 0 & 0 & 0 & 0 \\
\hline Pantala flavescens & 0.018 & 0.027 & 0 & 0.005 & 0 & 0 & 0 & 0.005 \\
\hline Ictinogomphus sp. & 0 & 0 & 0 & 0 & 0 & 0 & 0 & 0.005 \\
\hline Total of abundance & 0.271 & 0.11 & 0.057 & 0.039 & 0.005 & 0.039 & 0.027 & 0.024 \\
\hline Total of species & 15 & 8 & 7 & 6 & 1 & 6 & 2 & 4 \\
\hline
\end{tabular}

Table 2. Parasitoids abundance inhabiting non-crop plants and vegetables

\begin{tabular}{lcccccccc}
\hline \multicolumn{1}{c}{ Species } & \multicolumn{7}{c}{ Parasitoids abundance inhabiting non-crop plants dan vegetables (individual/hill) } \\
& Zinnia & Marigold & Kenikir & Sesame & Cowpea & Bitter melon & Cucumber & Ridged gourd \\
\hline Cryptochetum iceryae & 0.009 & 0.014 & 0.014 & 0.005 & 0.005 & 0 & 0 & 0 \\
Sarcophagidae (unknown sp.) & 0.009 & 0.018 & 0.009 & 0.005 & 0.005 & 0.014 & 0 & 0 \\
Blondelia nigripes & 0.014 & 0.018 & 0.023 & 0 & 0 & 0.005 & 0 & 0.005 \\
Total of abundance & 0.032 & 0.05 & 0.046 & 0.01 & 0.01 & 0.019 & 0 & 0.005 \\
Total of species & 3 & 3 & 3 & 2 & 2 & 2 & 0 & 1 \\
\hline
\end{tabular}


Table 3. Herbivore abundance inhabiting non-crop plants and vegetables

\begin{tabular}{|c|c|c|c|c|c|c|c|c|}
\hline \multirow{2}{*}{ Species } & \multicolumn{8}{|c|}{ Herbivore abundance inhabiting non-crop plants and vegetables (individual/hill) } \\
\hline & Zinnia & Marigold & Kenikir & Sesame & Cowpea & Bitter melon & Cucumber & Ridged gourd \\
\hline Chrysolina coerulans & 0.018 & 0 & 0.005 & 0.005 & 0 & 0.014 & 0.009 & 0.009 \\
\hline Aulacophora frontalis & 0 & 0.005 & 0 & 0 & 0 & 0.073 & 0.014 & 0.482 \\
\hline Aulacophora indica & 0 & 0 & 0 & 0 & 0 & 0.005 & 0.151 & 0 \\
\hline Charidotella sp. & 0 & 0 & 0 & 0 & 0 & 0 & 0.005 & 0 \\
\hline Epilachna dodecastigma & 0 & 0 & 0 & 0 & 0 & 0.059 & 0.005 & 0.023 \\
\hline Cletus trigonus & 0.036 & 0.009 & 0.005 & 0 & 0 & 0.032 & 0 & 0 \\
\hline Amata nigriceps & 0.018 & 0.045 & 0 & 0 & 0.018 & 0.050 & 0.009 & 0 \\
\hline Petrophora sp. & 0.005 & 0 & 0 & 0 & 0 & 0 & 0 & 0 \\
\hline Perizoma sp. & 0 & 0.005 & 0 & 0 & 0 & 0 & 0 & 0 \\
\hline Pelopidas thrax & 0.291 & 0.041 & 0.036 & 0 & 0 & 0.077 & 0.005 & 0 \\
\hline Spodoptera sp. & 0.009 & 0 & 0 & 0 & 0 & 0.009 & 0 & 0 \\
\hline Eurema blanda & 0.009 & 0 & 0.023 & 0 & 0 & 0.014 & 0 & 0 \\
\hline Aporia sp. & 0.009 & 0.009 & 0.005 & 0 & 0 & 0 & 0 & 0 \\
\hline Valanga nigricornis & 0.123 & 0.041 & 0.032 & 0.045 & 0 & 0.050 & 0.100 & 0 \\
\hline Acrida turrita & 0.032 & 0.023 & 0.005 & 0.014 & 0 & 0 & 0 & 0.005 \\
\hline Oxya chinensis & 0.041 & 0 & 0 & 0 & 0 & 0 & 0 & 0 \\
\hline Tetrix subulata & 0 & 0 & 0.005 & 0 & 0 & 0 & 0 & 0 \\
\hline Total of abundance & 0.591 & 0.178 & 0.116 & 0.064 & 0.018 & 0.383 & 0.298 & 0.519 \\
\hline Total of species & 11 & 8 & 8 & 3 & 1 & 10 & 8 & 4 \\
\hline
\end{tabular}

Table 4. Neutral insect abundance inhabiting non-crop plants and vegetables

\begin{tabular}{lcccccccc}
\hline \multirow{2}{*}{ Species } & \multicolumn{7}{c}{ Neutral insect abundance inhabiting non-crop plants and vegetables (individual/hill) } \\
& Zinnia & Marigold & Kenikir & Sesame & Cowpea & Bitter melon & Cucumber & Ridged gourd \\
\hline Chironomidae (unknown sp.) & 0.005 & 0 & 0 & 0 & 0 & 0 & 0 & 0 \\
Rainieria antennaepes & 0.036 & 0.014 & 0.023 & 0.009 & 0.005 & 0 & 0.005 & 0.005 \\
Neomyia cornicina & 0.009 & 0.005 & 0.018 & 0.027 & 0 & 0 & 0 & 0 \\
Chloromyia farmosa & 0.005 & 0 & 0.014 & 0 & 0 & 0 & 0 & 0.005 \\
Hermetia sp. & 0.005 & 0 & 0 & 0 & 0 & 0 & 0 & 0 \\
Tipula maxima & 0.045 & 0.009 & 0.014 & 0.005 & 0 & 0 & 0.005 & 0 \\
Trigona sp. & 0.118 & 0.082 & 0.023 & 0 & 0 & 0.055 & 0 & 0.005 \\
Apis cerana & 0 & 0.014 & 0 & 0 & 0 & 0 & 0 & 0 \\
Odontoponera transversa & 0 & 0.009 & 0 & 0.273 & 0.815 & 0 & 0 & 0.345 \\
Total of abundance & 0.223 & 0.133 & 0.092 & 0.314 & 0.82 & 0.055 & 0.01 & 0.36 \\
Total of species & 7 & 6 & 5 & 4 & 2 & 1 & 2 & 4 \\
\hline
\end{tabular}

\section{Arthropod community and guilds inhabiting non-crop plants and vegetables}

The arthropod community inhabiting non-crop plants and vegetables varied between plant species. Guild of herbivores was predominantly found in all of the non-crop plants and vegetable species, except sesame and cowpea (Figure 2). The sesame and cowpea were dominated by a neutral insect community, primarily Odontoponera transversa.

The arthropod community inhabiting non-crop plants and vegetables varied between plant species (Figure 3). They were dominated by four families, namely Hesperidae, Apidae, Formicidae, and Chrysomelidae. Arthropods inhabiting Zinnia sp. and C. caudatus were dominated by the Hesperidae; the marigolds were dominated by the
Apidae; the sesame and cowpea were dominated by Formicidae; and the bitter melon, cucumber, and ridged gourd were dominated by Chrysomelidae.

The highest abundance predators inhabiting non-crop plants was found in zinnia. The highest abundance of predators inhabiting zinnia was followed by that of herbivores and neutral insects (Figure 4). There was a link among the abundance of predators, herbivores, and neutral insects inhabiting the plants. The highest abundance of predators inhabiting vegetables was found in bitter melons, followed by parasitoids and herbivores. The high abundance of predators in bitter melons was not followed by that of neutral insects. The highest abundance of neutral insects in vegetables was found in cowpeas. 


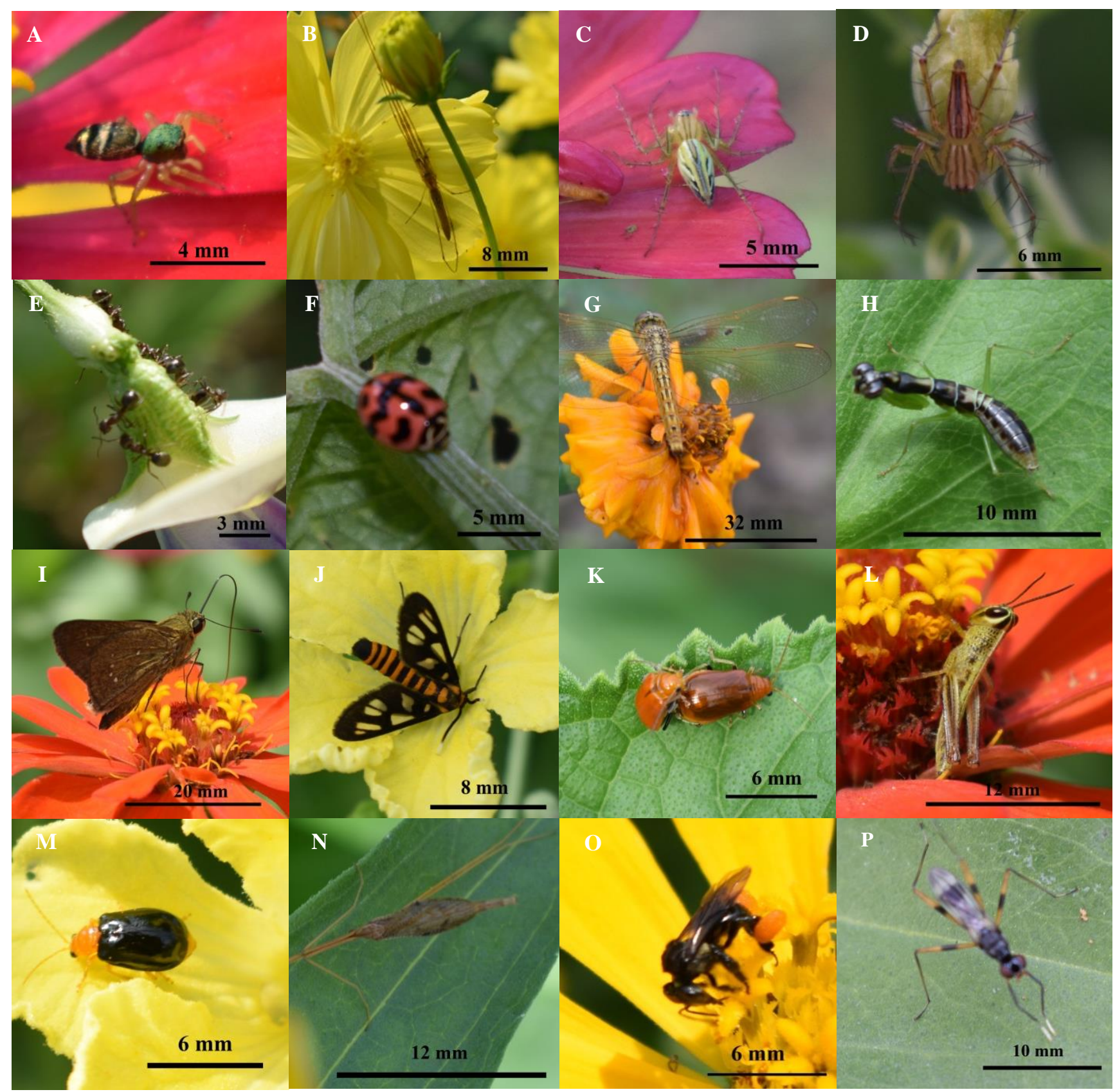

Figure 1. Dominant arthropod species inhabiting non-crop plants and vegetables: Cosmophasis sp. (A), Tetragnatha mandibulata (B), Oxyopes javanus (C), Oxyopes sp. (D), Odontoponera transversa (E), Menochilus sexmaculatus (F), Pantala sp. (G), Odontomantis planiceps (H), Pelopidas sp. (I), Amata nigripes (J), Aulacophora indica (K), Valanga nigricornis (L), Aulacophora frontalis (M), Tipula sp. (N), Trigona sp. (O), and Rainieria antennaepes (P)

The abundance of four community guilds of arthropods inhabiting non-crop plants and vegetables had a different tendency (Figure 5). Predators visited non-crop plants and vegetables all day from morning to evening. Predators tended visit zinnia in the afternoon and evening, $C$. caudatus in the morning and evening, cowpea and bitter melon in the morning, and ridged gourd in the afternoon and evening. Parasitoids generally visited non-crop plants and vegetables in the morning, for example zinnia, marigolds, sesame, and bitter melons were visited at 07-08 a.m., while $C$. caudatus and cowpea were mostly visited at 09-10 a.m. However, ridged gourd was visited by parasitoids in the afternoon at 04-05 p.m. Among those flowers, the marigolds were the most chosen by the parasitoids. Herbivores visited non-crop plants and vegetables throughout the day, while many neutral insects visited non-crop plants and vegetables in the morning. 
The abundance of guild arthropods found in non-crop plants and vegetables fluctuated during one paddy planting season. When paddy was initially planted, the abundance of arthropods found in non-crop plants and vegetables tended to be lower and continued to increase and reached a peak in the milky stage (56-70 DAT), nearing the harvest it tended to decline. During one planting season, the abundance of herbivores in zinnia, bitter melons, cucumber, and ridged gourd was always higher compared to other guilds, whereas in sesame and cowpeas, the abundance of neutral insects was always high (Figure 6). The abundance of predators and herbivores was highest in zinnia., The abundance of predators tended to be affected by the fluctuations of herbivores' abundance.

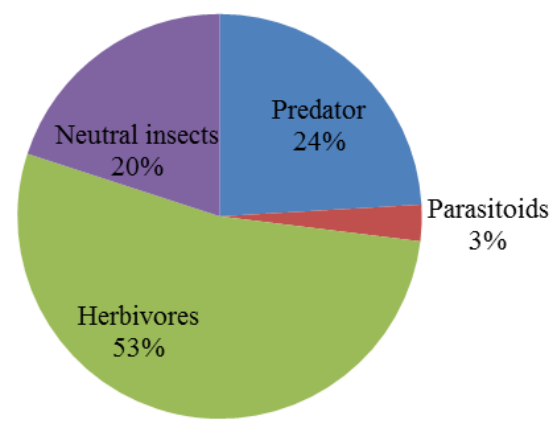

$\mathbf{A}$

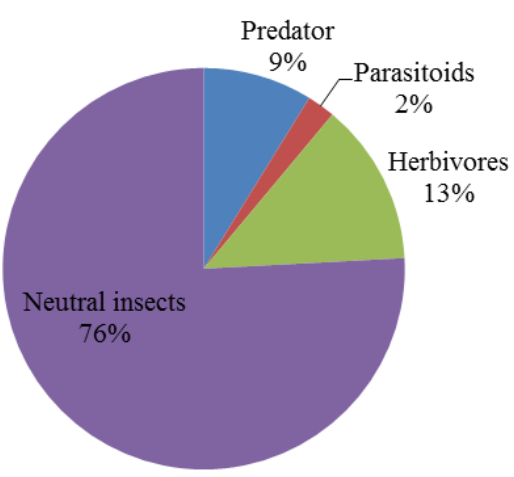

D

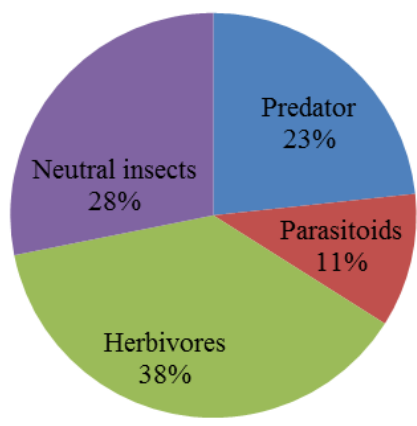

B

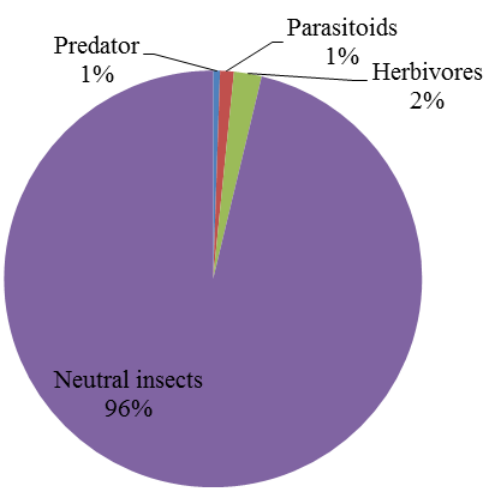

$\mathbf{E}$

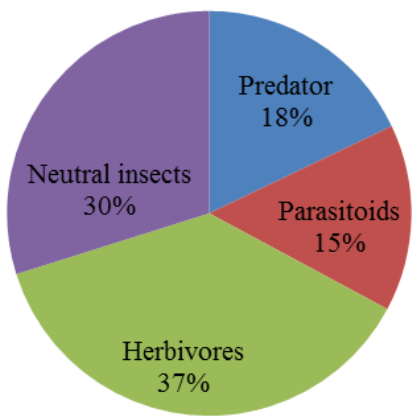

C

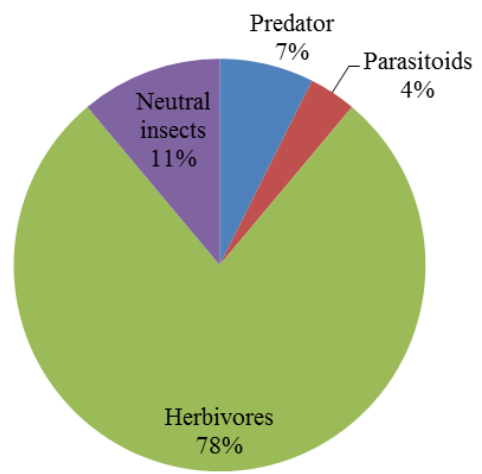

F

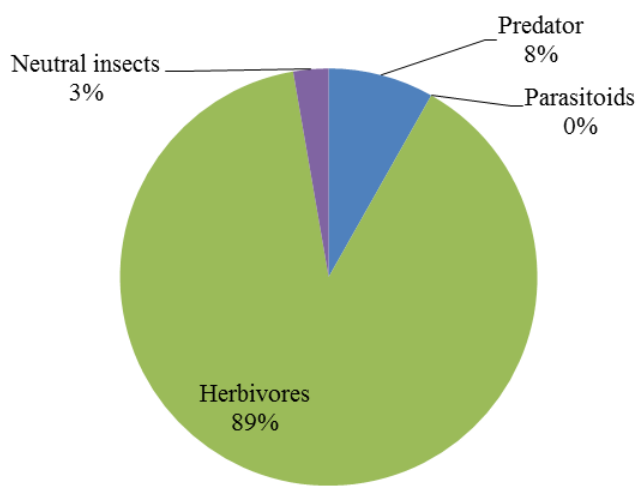

G

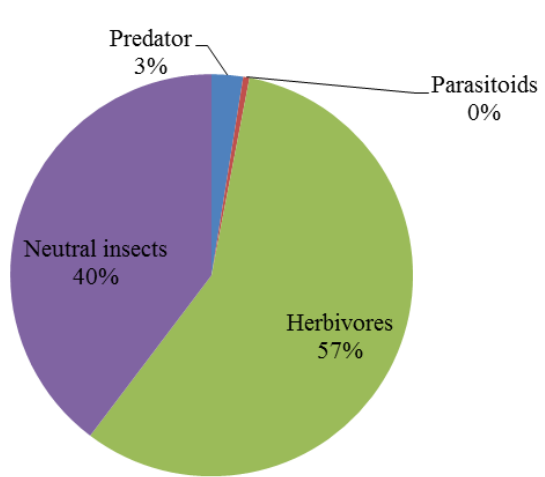

H

Figure 2. Proportion of arthropod guilds inhabiting non-crop plants dan vegetables: zinnia (A), marigold (B), kenikir (C), sesame (D), cowpea $(\mathrm{E})$, bitter melon $(\mathrm{F})$, cucumber $(\mathrm{G})$, and ridged gourd $(\mathrm{H})$ 

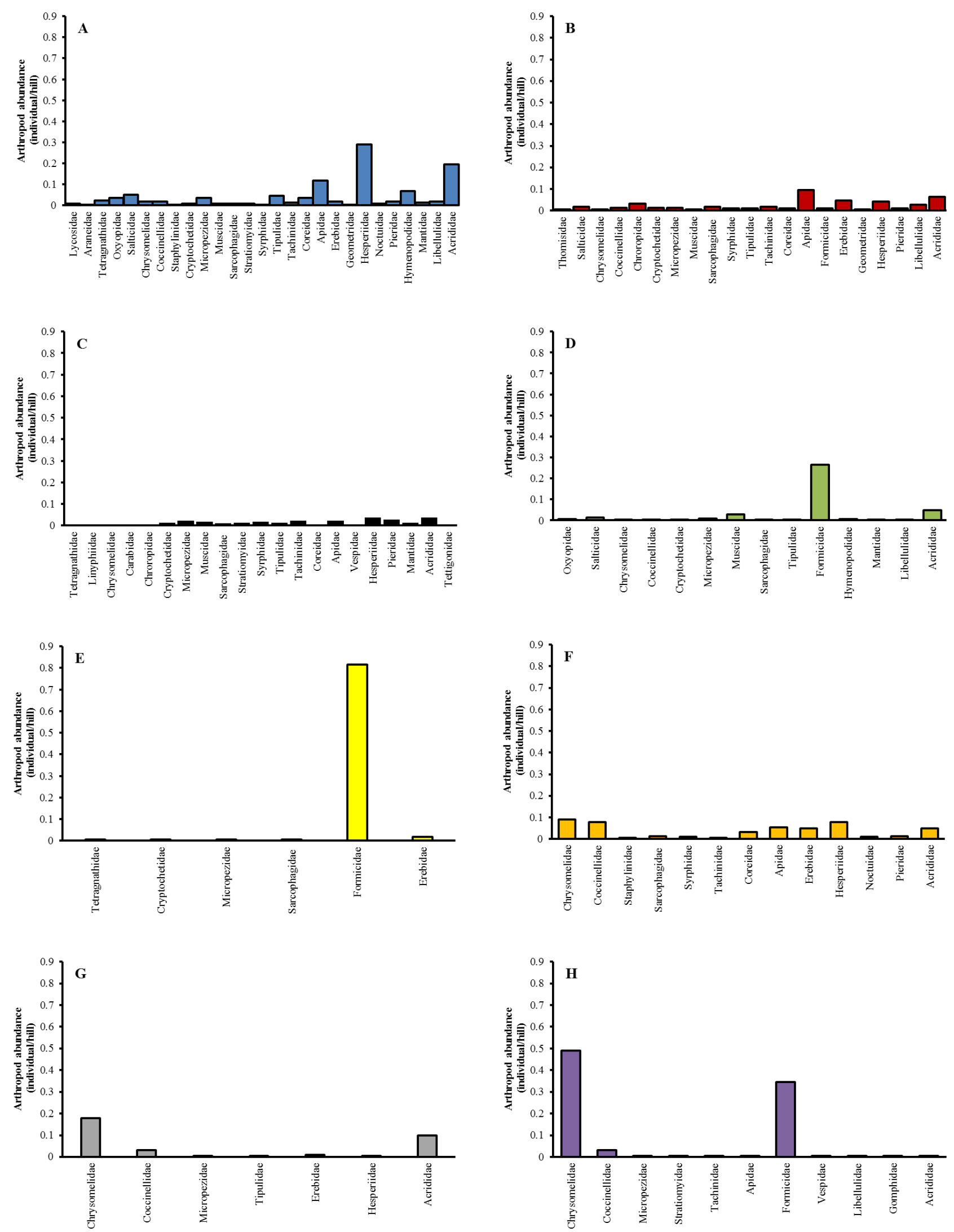

Figure 3. The mean abundance of arthropod family inhabiting non-crop plants and vegetables: zinnia (A), marigold (B), kenikir (C), sesame (D), cowpea (E), bitter melon $(F)$, cucumber $(G)$, and ridged gourd $(H)$ 

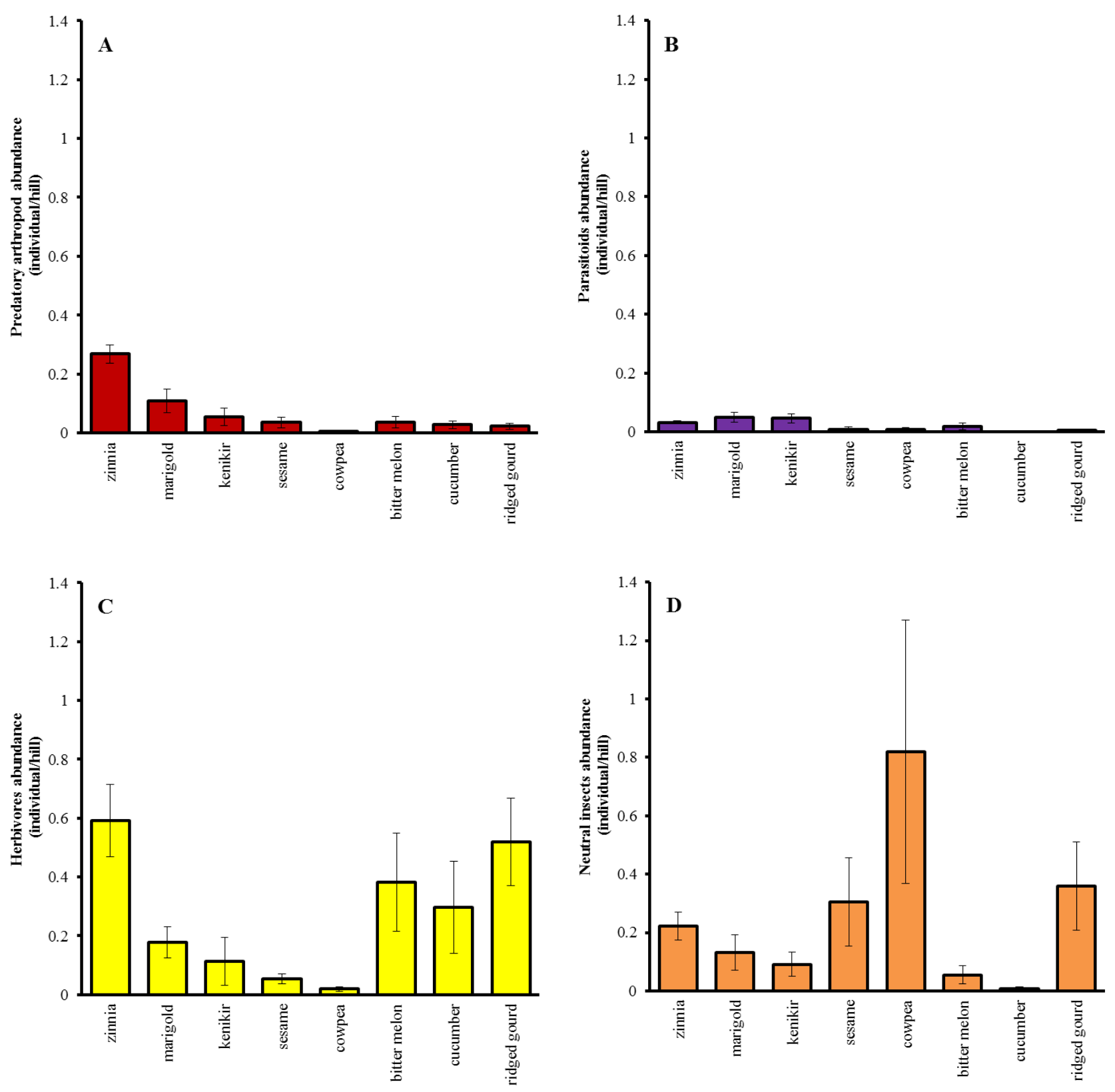

Figure 4. Guild abundance of predatory arthropod (A), parasitoids (B), herbivores (C), and neutral insects (D) inhabiting non-crop plants and vegetables

\section{Discussion}

Cosmophasis sp., T. mandibulata, O. javanus, Oxyopes sp., O. transversa, M. sexmaculatus, Pantala sp., and $O$. planiceps were paddy pest insect predators in this study. In line with Tahir et al. (2009), T. mandibulata are predators of Homoptera and Lepidoptera on paddy. O. javanus and Oxyopes spp. can attack, among others, Sogetella furcilera, and Scripophaga innotata on paddy in Pakistan (Tahir et al. 2009). M. sexmaculatus and Coccinellidae are generalist predators (Karindah, 2011) able to prey on N. virescens and N. lugens on paddy in India (Shanker et al. 2018).
At zinnia and bitter melon, the abundance of predators is higher than the abundance in six other plant species. Zinnia is preferred because of its longer blossoming period, and Wahocho et al. (2016) stated that Zinnia sp. can bloom for 23,67 days (Wahocho et al. 2016). Bitter melon has a yellow color preferred by the predatory arthropods compared to other colors. In line with the study of RochaFilho and Rinaldi (2011), arthropods prefer yellow flowers rather than white and pink flowers. In this study, the abundance of herbivores in zinnia and bitter melons can affect the abundance of these generalist predators. This phenomenon is common because generalist predators look 
for prey (Karenina et al. 2019). Zinnia and bitter melon are also the most chosen parasitoids for their habitat. The shape of the rosette flower of Zinnia sp. and bitter melon is highly attracted to predators and parasitoids. In line with the opinion of Jennings et al. (2017), the rosette-shaped flowers are visited by arthropods longer. Pollen and nectar existing in non-crop plants flowers and vegetables can also increase the attractiveness of flowers for niche arthropods, such as spiders (Eggs and Sanders 2013) and parasitoids (Foti et al. 2017).

The guild of herbivores dominated in all of plant species except sesame and cowpea. The species are Valanga nigricornis, Acrida turrita, and Oxya chinensis, which are grasshoppers and not key pests. However, the presence of herbivores in these plants is useful for prey generalist predators which are natural enemies of key pests in paddy. In herbivores of non-crop plants and vegetables, there are no key pests such as Nilaparvata lugens, Nephotettix virescens, Sogatella furcifera, and Leptocorisa acuta that attack paddy. Therefore, the presence of noncrop plants and vegetables does not function as an alternative habitat for key pests but acts as a habitat and niche for natural enemies and herbivores, which are not key pests. Still, the herbivores have an important role as alternative prey for predatory arthropods. Settle et al. (1996) pointed out that herbivores, which are not key pests, are also important in the presence of agroecosystems for prey generalist predators, and so are neutral insects that are important as stocks of predator-prey if the key pests are not found in paddy.
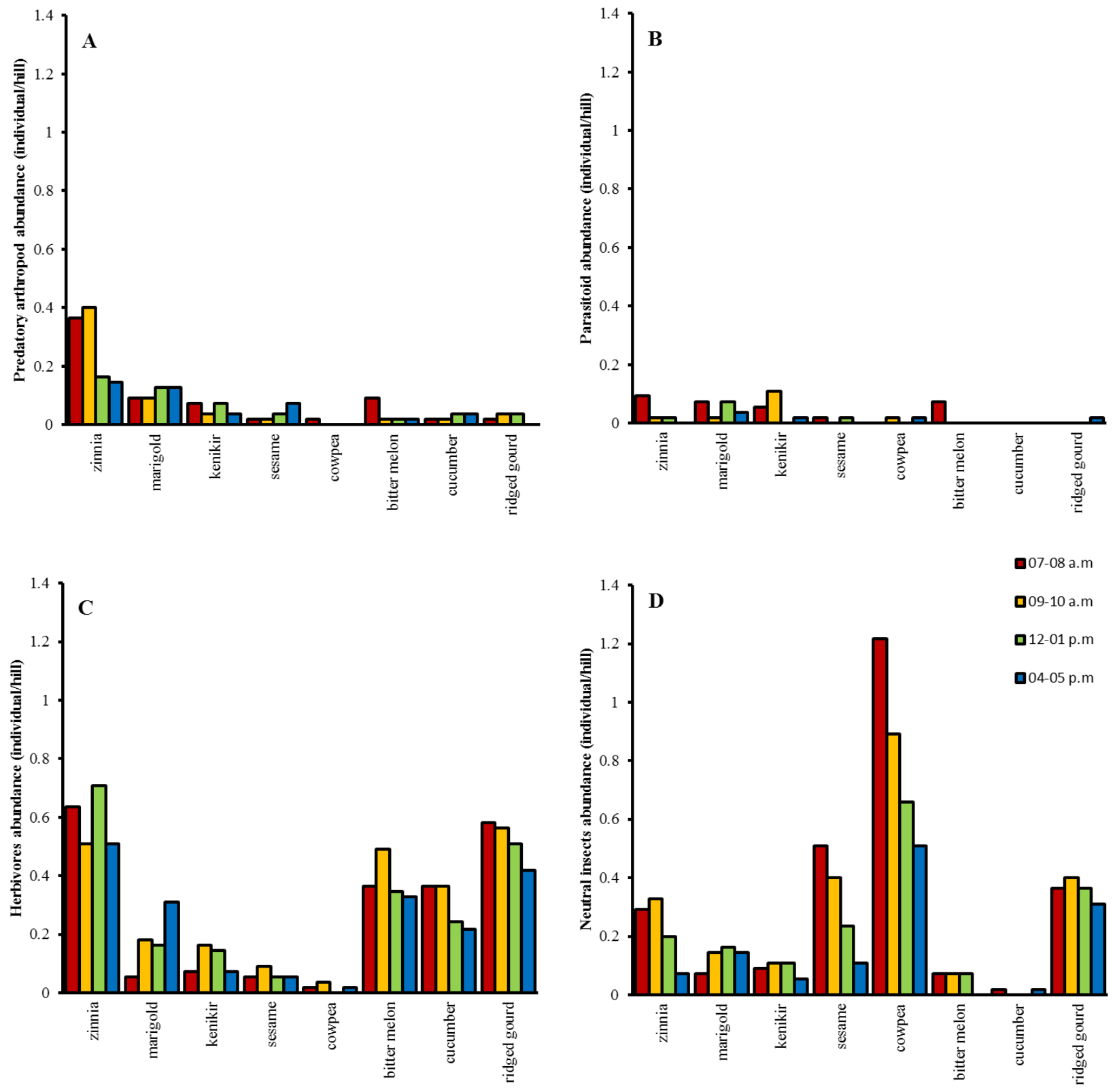

Figure 5. Guild abundance of predatory arthropod (A), parasitoids (B), herbivores (C), and neutral insects (D) inhabiting non-crop plants and vegetables at 07-08 a.m, 09-10 a.m, 12-01 p.m, 04-05 p.m 

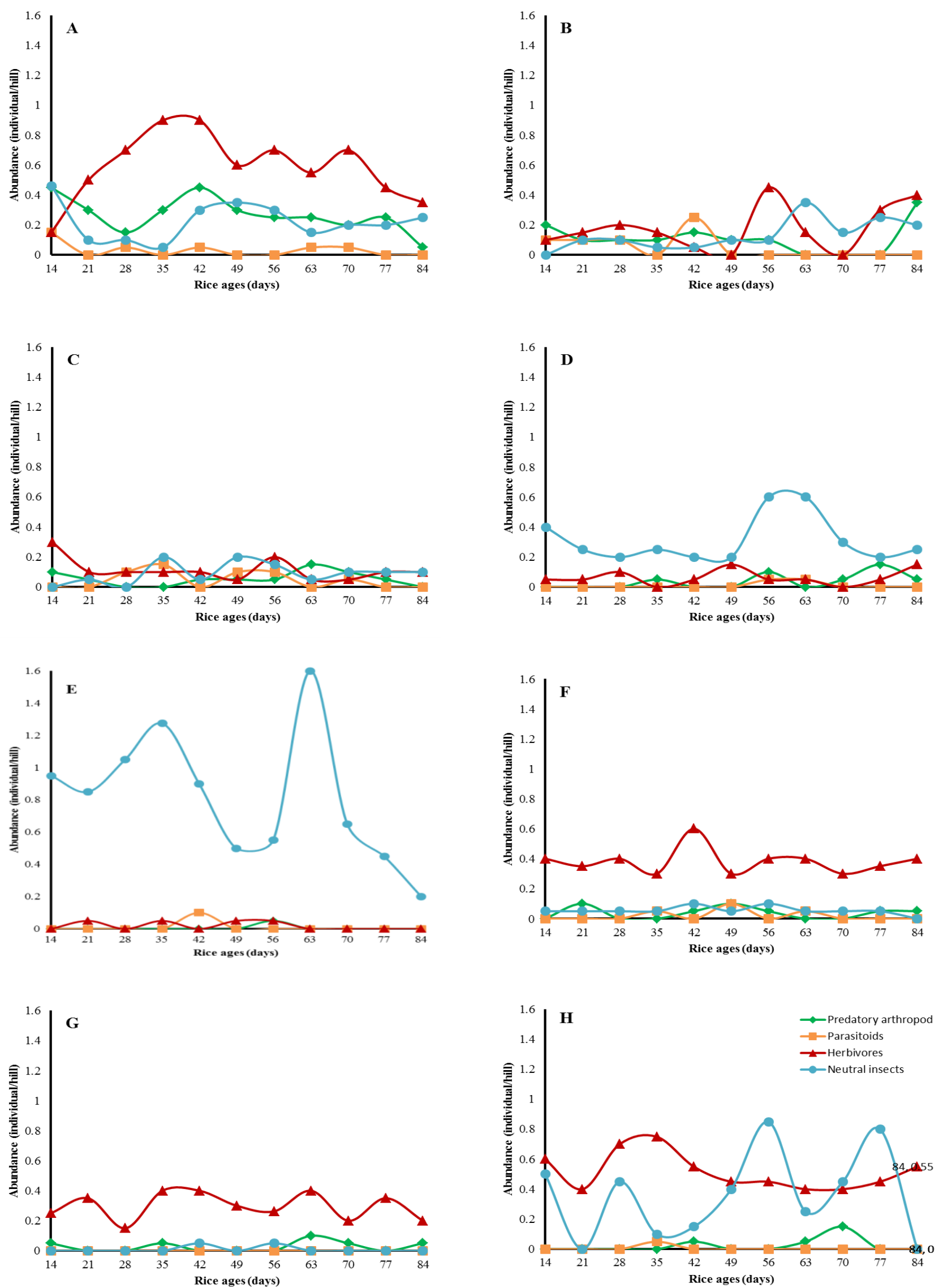

Figure 6. Abundance arthropod inhabiting non-crop plants and vegetables in the period 14-84 days after transplanting: zinnia (A), marigold (B), kenikir (C), sesame (D), cowpea (E), bitter melon (F), cucumber $(\mathrm{G})$, and ridged gourd $(\mathrm{H})$ 
In this study, $O$. transversa is an ant classified as a neutral insect commonly found in sesame and cowpea because the ant eats of pollen and nectar of both plants. The presence of ants (Formicidae) in sesame and cowpea can reduce the arrival of parasitoids and predators in these plants. The presence of the ants reduces the comfort of parasitoids and predatory arthropods to settle and look for a host or prey. In line with the results of the research conducted by Sanders et al. (2011), ants can reduce spider activity in suppressing and reducing herbivores populations. Species diversity and spider abundance decrease significantly when the habitat is inhabited by ants (Stefani et al. 2015). Consequently, sesame and cowpea are less suitable to be used as refugia functioning to conserve parasitoids and predatory arthropods, which are natural enemies of paddy pests.

The highest parasitoid abundance is found in marigolds which are commonly found in the morning. The marigold is preferred because it has a longer availability of pollen and nectar. This is because it is able to bloom for 48.47 days (Gobade et al. 2017). The marigold yellow color is an attraction for parasitoids to perch and suck the nectar. The shape and color of marigolds are the most ideal for parasitoids looking for food (Souza et al. 2019). Several types of parasitoid Brassicaceae pests found inhabiting marigolds, for example, the Family Braconidae, Ichneumonidae, Eulophidae, and Pteromalidae (Velcheva et al. 2017) and Tachinidae (Razmi et al. 201).

To sum up, the non-crop plants to be recommended for the conservation of parasitoids and predators of paddy pests are zinnia and marigolds, while the recommended crop is bitter melon. However, for increasing land productivity while at the same time preserving predators and parasitoids, planting bitter melon in paddy fields is more profitable than planting zinnia and marigolds.

\section{ACKNOWLEDGEMENTS}

This research was funded by Program of Professor Research Grant (Penelitian Unggulan Profesi untuk Guru Besar) of Universitas Sriwijaya, Ministry of Research, Technology and Higher Education, Republic of Indonesia with budget year of 2019, Contract Number: SP DIPA042.01.2.400953/2019 chaired by Siti Herlinda. We would like to thank to Program Beasiswa SDM IPTEK, Ministry of Research, Technology, and Higher Education that has given a scholarship for Tili Karenina, a postgraduate student.

\section{REFERENCES}

Barrion A, Litsinger J. 1995. Riceland spiders of South and Southeast Asia. Entomology Division International Rice Research Institute, Philippines.

Desai SD, Swaminathan R, Desai VS. 2017. Effect of habitat manipulation on infestation of paddy leaf folder, Cnaphalocrocis medinalis (Guenee). Int J Curr Microbiol App Sci 6: 1469-1477.

Eggs B, Sanders D. 2013. Herbivory in spiders: The importance of pollen for orb-weavers. PLoS ONE 8 (11): 1-5.
Foti MC, Rostás M, Peri E, Park KC, Slimani T, Wratten SD, Colazza S. 2017. Chemical ecology meets conservation biological control: identifying plant volatiles as predictors of floral resource suitability for an egg parasitoid of stink bugs. J Pest Sci 90 (1): 299-310.

Ganai SA, Ahmad H, Sharma D, Sharma S. 2017. Diversity of arthropod fauna associated with marigold (Tagetes erecta L.) in Jammu. J Entomol Zool Stud 5: 1940-1943.

Gobade N, Gajabhiye R, Girange R, Siwjanya P, Moon S. 2017. Evaluation of marigold genotypes for growth and flowering parameters under vidharbha condition. J Soils Crop 27: 132-135.

Hassan K, Pervin M, Mondal F, Mala M. 2016. Habitat management: A key option to enhance natural enemies of crop pest habitat: key regulator of natural 4: 50-57.

Heinrichs EA. 1994. Biology and management of rice insect. International Rice Research Institute, Los Banos, Philippines.

Herlinda S, Yudha S, Thalib R, Khodijah, Suwandi, Lakitan B, Verawaty M. 2018. Species richness and abundance of spiders inhabiting rice in fresh swamps and tidal lowlands in South Sumatra, Indonesia. J ISSAAS 24: 82-93.

Herlinda S, Yusticia SR, Irsan C, Asmara B, Hadi R. 2019. Abundance of arthropods inhabiting canopy of rice cultivated using different planting methods and varieties. J Biopest 12: 7-18.

Jennings DT, Longcore JR, Bird JE. 2017. Spiders (Araneae) inhabit Lepidopteran-feeding shelters on ferns. J Acad Entomol Soc 13: 5-14.

Johari A, Herlinda S, Irsan C, Pujiastuti Y. 2016. Phenomenon of Thrips (Thysanoptera) attack on chili plant (Capsicum annuum). Am J Agric Biol Sci 11: 103-109.

Johari A, Herlinda S, Pujiastuti Y, Irsan C, Sartiami D. 2014. Morphological and genetic variation of Thrips parvispinus (Thysanoptera: Thripidae) in chili plantation (Capsicum annuиm L .) in the lowland and highland of Jambi Province, Indonesia. Am J Biosci 2: 17-21.

Kalshoven LG. 1981. The pest of crops in Indonesia. Van Hoeve, Jakarta: PT. Ichtiar Baru.

Karenina T, Herlinda S, Irsan C, Pujiastuti Y. 2019. Abundance and species diversity of predatory arthropods inhabiting rice of refuge habitats and synthetic insecticide application in freshwater swamps in South Sumatra, Indonesia. Biodiversitas 20 (8): 2375-2387.

Karindah SRI. 2011. Predation of five generalist predators on brown planthopper (Nilaparvata lugens Stål). J Entomol Indonesia 8: 55-62.

Lakitan B, Hadi B, Herlinda S, Siaga E, Widuri LI, Kartika K, Lindiana L, Yunindyawati Y, Meihana M. 2018. Recognizing farmers' practices and constraints for intensifying rice production at Riparian Wetlands in Indonesia. NJAS - Wageningen J Life Sci 85: 10-20.

Mcalpine JF, Peterson BV, Shewel GE, Teskey HJ, Vockeroth JR, Wood DM. 1987. Manual of Nearctic Diptera. Agriculture Canada. Research Branch.

McCabe E, Loeb G, Grab H. 2017. Responses of crop pests and natural enemies to wildflower borders depend on functional group. Insects 8 : $1-8$

Mulyani A, Sarwani M. 2013. The characteristics and potential of sub optimal land for agricultural development in Indonesia. J Sumberdaya Lahan 7: 47-55. [Indonesian].

Prabawati G, Herlinda S, Pujiastuti Y. 2019. The abundance of canopy arthropods in South Sumatra (Indonesia) freshwater swamp main and ratooned rice applied with bioinsecticides and synthetic insecticide. Biodiversitas 20: 2921-2930.

Razmi M, Karimpour Y, Safaralizadeh MH, Safavi AA. 2011. Parasitoid complex of cabbage large white butterfly Pieris brassicae (L.) (Lepidoptera, Pieridae) in Urmia with new records from Iran. J Plant Protection Res 51 (3): 248-251.

Rocha-Filho LC, Rinaldi IMP. 2011. Crab spiders (Araneae: Thomisidae) in flowering plants in a Brazilian "Cerrado" ecosystem. Brazilian J Biol71 (2): 359-364.

Saleh A, Siregar AZ. 2017. Impact of natural enemies to leaf eating caterpillar population on oil palm in North Sumatra, Indonesia. Int J Sci Technol Res 6: 189-192.

Settle WH, Ariawan H, Astuti ET, Cahyana W, Hakim AL, Hindayana D, Lestari AS, Pajarningsih. 1996. Managing tropical rice pests through conservation of generalist natural enemies and alternative prey. Ecology 77 (7): 1975-1988.

Shanker C, Chintagunta L, Muthusamy S, Vailla S, Srinivasan A, Katti G. 2018. Flora surrounding rice fields as a source of alternative prey for 
Coccinellids feeding on the pests of rice. European J Entomol 115: 364-371.

Siaga E, Lakitan B, Hasbi H, Bernas SM, Widuri LI, Kartika K. 2019 Floating seedbed for preparing rice seedlings under unpredictable flooding occurrence at tropical riparian wetland 25: 326-336.

Souza IL, Tomazella VB, Santos AJN, Moraes T, Silveira LCP. 2019. Parasitoids diversity in organic sweet pepper (Capsicum annиит) associated with basil (Ocimum basilicum) and marigold (Tagetes erecta). Brazilian J Biol 6984: 1-9.

Stefani V, Pires TL, Torezan-Silingardi HM, Del-Clari K. 2015. Beneficial effects of ants and spiders on the reproductive value of Eriotheca gracilipes (Malvaceae) in a tropical savanna. PLoS ONE 10 (7): 1-12.
Suwandi, Ammar M, Irsan C. 2012. Application of extract compost increased yield and suppressed the diseases of ratoon rice crop in tidal swamp of Banyuasin Regency. J Lahan Suboptimal 1: 116-122. [Indonesian].

Tahir HM, Butt A, Sherawat SM. 2009. Foraging strategies and diet composition of two orb web spiders in rice ecosystems. J Arachnol 37: $357-362$.

Velcheva N, Atanassov A, Ilieva Z. 2017. New data of Bulgarian parasitoid entomofauna and contributions to host-parasitoid interactions. Bulg J Agric Sci 23: 589-593.

Wahocho SA, Miano TF, Memon NUN, Wahocho NA. 2016. Photoperiodic effect on vegetative growth and flower quality of zinnia (Zinnia elegans Jacq.). Sarhad J Agric 32: 316-324. 